\title{
Distribution, size and bacterial colonization of transparent exopolymer particles (TEP) in the ocean
}

\author{
U. Passow ${ }^{1}$, A. L. Alldredge ${ }^{2}$ \\ ${ }^{1}$ Marine Science Institute, ${ }^{2}$ Biological Sciences, University of California, Santa Barbara, California 93106, USA
}

\begin{abstract}
The distroution, abundance, and size spectra of transparent exopolymer particles (TEP) generated from excretion produrts of phytoplankton were investigated. TEP was found at all stations studied, but abundance and total quantity of TEP varied by 4 orders of magnitute among coastal, slope and oceanic environments. Abundance and size distributions of TEP appeared to be related to plankion composition. Abundince lended to be higher in coastal and shallow waters compared to oceanic and deep waters respectively. The average size of TEP was appreriably larger at stations where diatoms dominated phytoplanktun. Size distributions of TEP generally followed a power-law function. except when aggregation dominated interectuon of particles. The type of size distribution of TEP may allow us to predict the tendency of a plinkton community to aggregate. General differences in the shape of size spcctra of TEP indicate TEP generaled by diatoms to be slickier and more fractal compared ta TEP generated by non-diatom plankton. All TEP were colonized by bacteria, but no correlation was found between numbers of attached bacteria on individual TEP and the respecive size of TEP. Barteria density on TEP, however, decreased with increasing size of TEP exponentially. Between 2 and $25 \%$ of the tolal bacterial population were attached to TEP. Tolal number of bacteria were not correlated with told quantity of TEP. suggesting that no simple overall relationship exists between TEP and baccerią.
\end{abstract}

KEY WOROS. TEP - Altached bacteria $\cdot$ Size frequency distributions

\section{INTRODUCTION}

A new class of transparent particles, called TEP (transparent exopolymer particles), has recently been discovered to be abundant in the ocean (Alldredge et aL. 1993). TEP can be made visible by staining with alcian blue, a stain specific for polysaccharides. TEP are presumably produced from dissolved carbohydrate polymers exuded by phytoplankton and bacteria. In seawater these polymer molecules align and coalesce via cation bridging, forming invisible particles ranging from microns to hundreds of microns in size. While preliminary studies indicate that TEP are important in the aggregation of diatom blooms, provide the matrix of marine snow, serve as a substrate and microhabitat for attached bacteria, and represent an imporlant pathway for the transformation of dissolved to particulate matter (Alldredge et al. 1993, Passow et al. 1994), the distribution, abundance, and characteristics of this new class of particles remain largely unknown.

Information on the abundance and size distributions of TEP produced in different oceanographic regimes and by different species of phytoplankton is necessary to accurately assess the significance of this new particle class to the biology and chemistry of the pelagic zone and to identify taxa most likely to produce TEP abundantly. In the present study we compare the abundance and size distribution of IEP generated by different phyloplankton species and determine the size distributions and abundances of TEP in coastal and oceanic environments in relation to plankton composition. The role of TEP as a site for bacterial attachment in different marine environments is also investigated. 


\section{METHOD}

Cultures and sample collection. Abundance and particle size frequency distributions of TEP were investigated in batch cultures and seawater. Batch cultures of Chaetoceros gracilis. Nitzschia angularis, Thalassiosira weissflogii and colonial Phaeocystis were grown in $\mathrm{f} / 2$ medium with silica at $12^{\circ} \mathrm{C}$ and $100 \mu \mathrm{E}$ $\mathrm{m}^{-2} \mathrm{~s}^{-1}$ light (12:12 h cycle) in unbubbled Fernbach flasks. Care was taken to prepare the media free of precipitates, as salt precipitates generated during autoclaving produce stainable artefacts which are difficult to distinguish from TEP. Controls for precipitates were made for each batch of media.

Seawater samples were collected on several occasions during June and July 1992 off Santa Barbara, California, USA $\left(34^{\circ} 20^{\prime} \mathrm{N}, 119^{\circ} 50^{\prime} \mathrm{W}\right)$, by scuba divers at 5 to $20 \mathrm{~m}$ depths. Seawater samples were col. lected with Niskin bottles in August 1992 from 0 to $400 \mathrm{~m}$ depths in Monterey Bay, California $\left(36^{\circ} 48^{\circ} \mathrm{N}\right.$. $121^{\circ} 53^{\circ} \mathrm{W}$ and $36^{\circ} 46^{\circ} \mathrm{N}, 121^{\circ} 57^{\circ} \mathrm{W}$ ) and in March 1993 from 300 to $1500 \mathrm{~m}$ depths in the open Atlantic off Bermuda (BATS Stn $54 ; 31^{\circ} 50^{\circ} \mathrm{N}, 64^{\circ} 10^{\circ} \mathrm{W}$ ).

Slide preparation and enumeration. Semi-permanent slides of TEP were prepared in duplicate by passing 1 to $20 \mathrm{ml}$ of seawater onto a $0.4 \mu \mathrm{m}$ polycarbonate filter (Poretics). TEP were stained on damp filters with an aqueous solution of $0.02 \%$ alcian blue ( $8 \mathrm{GX}$ ). a hydrophilic, catonic dye specific for polysaccharides. and $0.06 \%$ acetic acid. The staining solution was prefiltered through $0.2 \mu \mathrm{m}$ before use, as the stain aggregates with itself. The filter was fully covered with stain (about 400 to $500 \mu \mathrm{l}$ ) which was immediately sucked through (as staining is immediate). Since residual stain reacts with salts in seawater to create artefacts, funnels and base were nnsed with distilled water betore use. Vacuum pressure was kept low and constant. Filters were then transferred to slides and prepared according to the Filter-Transfer-Freeze (FTF) technique (Hewes \& Holm.Hansen 1983, Hewes et al. 1984). Blanks were prepared with 'clean' seawater (filtered repeatedly through $0.2 \mu \mathrm{m}$ ) or by dipping the filter into seawater before staining as described above.

All samples, except those from Bermuda, were prepared fresh Samples from Bermuda were preserved in buffered formalin $(0.5$ to $1 \%)$ and slides prepared within $2 \mathrm{wk}$ after fixation. Slides may be stored at room temperature in the dark for up to $6 \mathrm{mo}$.

Total bacteria abundances were enumerated on black polycarbonate filters (Poretics, $0.2 \mu \mathrm{m}$ ) after staining with acridine orange according to Hobbie et al. (1977). Samples were double-stained with DAPI (4',6-diamidino-2-phenylindole) and alcion blue to enumerate bacteria attached to TEP. Replicate sea. water samples were first stained in the funnel with
$0.5 \mathrm{ml}$ DAPI $\left(25 \mu \mathrm{m} \mathrm{ml}^{-1}\right)$ for 5 to $10 \mathrm{~min}$, filtered onto $0.2 \mu \mathrm{m}$ polycarbonate filters (Poretics) (Porter \& Feig 1980, King \& Parker 1988) and then stained with alcian blue as described above. The FTF technique has been reported to yield accurate estimates of bacterial abun. dances (King \& Parker 1988) which we could confirm (Alldredge et al. 1993)

Phytoplankton and TEP (>3 $\mu \mathrm{m}$ ) were counted in 20 to 150 fields on each slide at $200 \times$ magnification with a compound light microscope. TEP $(N)$ were assigned to 6 size classes by maximum length, with each size increment (d/) double the length of the previous. The area of TEP wis calculated based on measurements of the actual size of 20 representive TEP in each size class for each set of samples. Although the shape of TEP varted and often was amorphous, TEP in any one sample and size class were of similar shape and the area of TEP on filters can be estimated fairly accurately with this method (Passow \& Alldredge unpubl.).

Total bacteria and bacteria attached to TEP were counted using a Zeiss epifluorescence microscope at a magnification of $800 \times$. Ten fields were counted from each of 2 replicate stides for total bacteria counts. Bac. teria associated with 20 to 30 TEP per slide were enumerated by switching between UV and visible Lght and individual TEP were sized. The average numbers of bacteria per area of TEP were calculated for each particle. Estimates of bacteria attached to TEP are considered conservative because TEP are presumably 3-dimensional. making enumeration on 1 plane difficult, and thin sheets of TEP were difficult to discern. TEP concentrations in Bermuda samples were too low to enumerate attached bacteria

Impact of formalin fixation. Controls showed that formalin itself does not interfere with the stain. However. since the binding capacity of alcian blue depends on the pH (Parker \& Diboll 1966, Horobin 1988), preservation techniques which alter the $\mathrm{pH}$ of the sample are expected to affect quantitative results. We found however that small changes in $\mathrm{pH}(8.2$ to 8.7$)$ did not change the size or amount of stained particles.

We tested the impact of formalin preservation on TEP using samples collected during a diatom bloom and from a culture of colonial Phaeocystis. Slides from samples collected during a diatom bloom in June off Santa Barbara were prepared both from fresh samples and from aliquots which had been preserved in formalin $(0.5$ to $1 \%)$ for 6 mo. Comparisons of the particle size distributions of TEP in preserved and fresh aliquots revealed no significant difference $(t$-test, $d f=4$, $p>0.11$. although formalin-preserved samples appeared to slightly underestimate total TEP abundance-

Unpreserved, intact and healthy colonies of Phaeocystis did not stain with our method as stronger concentrations and longer staining times are needed to 
stain the colony matrix. However, formalin preservation leads to the discuption of the colony matrix and shreds of the matrix stain, rreating TEP-like artefacts. Fragile organisms like ciliates or athecate dinoflagellates often disintegrate in formalin and the cellular polysaccharides released may also create artefacts

Calculation of the fraction of bacteria attached to TEP. We calculated the fraclion of bacteria allached io TEP in 2 different ways from our counts. First, the percentage of altached bacteria was calculated directly for each double-stained slide irom microscope counts of Iree versus altached bacteria. Second, because the magnification needed to count bacleria is sometimes too high to simultaneously count large TEP representatively, we calculated the [raction of bacteria associated with TEP from (1) the size distribution of TEP (TEP slides). (2) the counts of total number of bacteria (acridine orange slides) and (3) the general relationship belween bacterial density on TEP (number of bacteria per area TEP) and TEP size derived from all counts of double-stained slides. In general, both cajculations gave similar results, although somelines the first method gave higher values. All values given in the present paper are calculated according to the second method and are considered conservative.

Particle-size distributions. Particla-size spectra of suspended matter in the ocean can often be fitted to a power-law distribution derived from a volume distribulion histogram that tepresents the distribution in which the volume of particles of cach size inlerval remains constant (Bader 1970, Sheldon el bi], 1972. Lerman 1979). Deviations from such a distribution maty give indications of physical or biological processes, such as aggregation, fragmenlation, dissolution, or consumption by animals, which alter the size distribution of particles.

Particle-size distributions of TEP were determined from microscopical enumerations. The mean maximal length value of each size interval $(l$, in $j \mathrm{~m})$ and the ratio between TEP abundance per interval and the size interval ( $\mathrm{dN} / \mathrm{dl}$, in $\mathrm{TEP} \mathrm{ml}^{-1} \mu \mathrm{m}^{-1}$ ) were plotted on $\log$ $\log$ coordinate graphs. The best fit lines were calculated based on a least-squares estimation of parameters $A$ and $b$ in the following power-law relationship

$$
\mathrm{d} N / \mathrm{d} l=A l^{-b}
$$

where $A$ and $b$ are constants. The slope of the size distributions plotted in log-log coordinates is given by the power exponent $b$ and describes the shape of the curve. A decrease in $b$ signilies a reduction in the percentage of small particles. A value of $b=4$ umplies equal particle volumes in each size class. A change in $A$ when $b$ remains constant signifies a change in the total number of particles in all size classes.
Particle-sizc distrubutions of TEP are based on the maximal length of TEP on filters. The actual size of TEP when suspended in seawater is presumably smaller than the size of TEP after they collapse on filters (Passow \& Alldredge unpubl). It is, however, assumed that the shape of the size distributions of TEP. i.e. the relative size of TEP, remains the same during filtration.

For the coastal data, regression lines were only calculated for samples where TEP occurred in at least 4 different size classes. All regressions of samples for which calculalions were possib]e (28 total) were statistically significant $(\rho<<0.01$, in most cases $p<0.001)$, except for 2 samples which did not follow a power-law distribution and were collected during the aggregation phase of a diatom bloom. TEP concentrations at the open ocean station of Bermuda (BATS) were low and regressions were calculated if TEP was lound in 3 or more size classes ( 9 out of 12 depths). Seven regressions were significant at the 0.05 level.

To assess how aggregation changes the size distro. ution of TEP, size distributions were calculated from a flocculation experiment with a batch culture of Chdeloceros gracilis conducted earlier (Passow et al. 1994). For that experiment the culture had been rotated for $20 \mathrm{~min}$ in a cuvette flocculator (Logan \& Kirchmann 1991) and subsamples had been collecled after 4,8 and $20 \mathrm{~min}$ of rotation at a shear of $30 \mathrm{~s}^{-1}$. Calculations were based on counts of TEP un 4 size clusw's between 20 and $500 \mu \mathrm{m}$.

\section{RESULTS}

\section{TEP in nature}

Abundance, size and vertical distribution

TEP was found in all natural seawater sámples investigated. Tolal number abundance and total area (estimate of guantity) of TEP, however, varied by 4 orders of magnitude $\left(10^{0}\right.$ lo $10^{-4}$ TEP $\mathrm{ml}^{-1}$ and 0.2 to $2000 \mathrm{~mm}^{2}$ $1^{-1}$ respectively) (Table 1 ). The length of individual TEP ranged from 3 to several hundred $\mu$ m. The average diameter of TEP ranged from $12 \mu \mathrm{m}$ at the beginning of the diatom bloom to $163 \mu \mathrm{m}$ during flocculation of the bloom. At Monterey Bay, the average diameter of TEP ranged between 8 and $13 \mu \mathrm{m}$, excepl 27 August 1992 at $10 \mathrm{~m}$ (where diatoms dominated the phytoplankton) when it was $151.1 \mathrm{~m}$. At the BATS station the average diameter ranged between 9 and $12 \mu \mathrm{m}$, except at $900 \mathrm{~m}$ where the average diameter was $23 \mathrm{\mu m}$.

Examples of vertical distribution patterns of TEP and cells at several stations are depicted in Fig. 1. TEP concentrations were generally higher in the trophogenic 
Table 1. Abundance, total ared and slope of size spectra of TEP (o, cf. Eq. 1$)$ for some typical somples. MB: Monterey Bay; SB: Santa Barbara: BATS: Bermuda. Data from duatom bloom from Alldredge ef al, (16,43)

\begin{tabular}{|c|c|c|c|c|c|}
\hline \multirow[t]{2}{*}{ Samples } & \multirow{2}{*}{ Environment } & \multirow{2}{*}{ Dominàtisg plankton } & \multicolumn{2}{|c|}{ TEP } & \multirow[t]{2}{*}{$b$} \\
\hline & & & $\begin{array}{l}\text { Abundance } \\
\text { (no. } \mathrm{ml}^{-1} \text { ) }\end{array}$ & $\begin{array}{c}\text { Area } \\
\left.\left(\mathrm{mm}^{2}\right)^{-1}\right)\end{array}$ & \\
\hline $24 \mathrm{Jul}, 10 \mathrm{~m}$ & Coastal SB & Clear & 25 & 1 & 2.8 \\
\hline 27 Aug. $76 \mathrm{ml}$ & Slope MB & Clear & 500 & 50 & 3.0 \\
\hline 26 Aug. $5 \mathrm{~m}$ & Coastal MB & Mixed & 4926 & 500 & 3.0 \\
\hline 26 Aug. $400 \mathrm{~m}$ & Coastal MB & Clear & 2448 & 140 & 3.6 \\
\hline BATS, $400 \mathrm{~m}$ & Oceanic & Clear & 2 & 0.2 & no \\
\hline 27 Aug, $10 \mathrm{~m}$ & Coastal MB & Diatoms & 877 & 290 & 2.7 \\
\hline 27 Aug. $5 \mathrm{~m}$ & Coastal MB & Dinoflagellates & $\$ 168$ & 650 & 3.0 \\
\hline 27 Aug. $20 \mathrm{~m}$ & Codstal MB & Dinoflagellates + Phaeocysis & 3741 & 270 & 3.4 \\
\hline BATS, $300 \mathrm{~m}$ & Oceanic & Clear & 3 & 0.3 & 3.7 \\
\hline BATS, $800 \mathrm{~m}$ & Oceanic & Clear & 6 & 0.7 & 3.4 \\
\hline BATS, $900 \mathrm{~m}$ & oceanic & Diatoms & 7 & 4.6 & 2.2 \\
\hline BATS, $1400 \mathrm{~m}$ & Oceanic & Clear & 2 & 0.2 & 2.8 \\
\hline 19 Jun, $10 \mathrm{~m}$ & Coastal SB & Diatom bloom & 357 & 130 & 1.7 \\
\hline 24 Јงก, $10 \mathrm{~m}$ & Coastal SB & Diatom bloom & 625 & 200 & 2.2 \\
\hline 29 Jun, $10 \mathrm{~m}$ & Coâstal SB & Diatom bloom & 193 & 2200 & - \\
\hline
\end{tabular}

(plankton-rich) zone than below (for example: Monterey Bay, 26 August 1992; Fig. 1a, b). TEP concentrations decreased parallel with concentrations of bacterio-, phyto- and protozooplankton at $20 \mathrm{~m}$. However. concentrations of TEP varied appreciably below the trophogenic zone and a relative high abundance was observed at $300 \mathrm{~m}$. Duatoms were rare at this slation, and microplankion svas dominated by dinoflagellates and ciliates.

Abundance and size of TEP may also vary within the trophogenic zone, appearing in accordance with changes in the plankton composition (Fig. 1 $\mathbf{c}$, d). In Monterey Bay (27 August 1992), TEP abundance was lowest at $10 \mathrm{~m}$, the depth of the diatom maximum (10 diatoms $\left.1^{-1}\right)$, and highest at $50 \mathrm{~m}$, the low'r end of the trophogenic zone. At $10 \mathrm{~m}$ the averasg stre of TEP was, however, very large. Dinoflagellates wre most abundant at the surface $\left(10^{4} \mathrm{l}^{-1}\right)$ and decreased continuously with depth. A small population of colonial Phaeocystis was present between 10 and $20 \mathrm{~m}$ depth. Bacteria concentrations decreased continuously with deplb

Compared to coastal stations, concentrations of TEP were extremely low at all depths (300 to $1400 \mathrm{ml}$ of the open ocean station (BATS) near Bermuda (Fig. 1 e. f). At Monterey Bay (26 August 1992), for example, about $2500 \mathrm{TEP} \mathrm{ml} \mathrm{ml}^{-1}$ were observed at $400 \mathrm{~m}$ whereas only 2 TEP $\mathrm{ml}^{-1}$ prevailed at $400 \mathrm{~m}$ in the open Atlantic. Total quantity of TEP (expressed as total area) was also 3 to 4 orders of magnitude lower compared to coastal waters. Above $800 \mathrm{~m}$ and below $1000 \mathrm{~m}$ concentrations were very uniform, but a peak in TEP numbers was observed at $900 \mathrm{~m}$. Plankton concentrations were low ( $<100$ cells $1^{-1}$ ) at all depths, except at $900 \mathrm{~m}$. Several species of mostly Chaetoceros were observed at concentrations of $1.6 \times 10^{5}$ cells $]^{-1}$ at $900 \mathrm{~m}$.

\section{Size djstributions}

Although total abundance of TEP was extremely variable, the general shapes of the size frequency distributions were similar (Fig. 2a). All but 2 of the size frequency spectra of TEP analyzed $(n=33)$ follow a Pareto (power-law) distribution (Eq. 1, Fig. 2a to d). However, both at Monterey Bay (27 August) and at BATS the shapes (b-values) of the power-law distribu. tons at different depths differ (Fig. 2b, c). We classified all frequency distributions in to 2 main groups and 1 transition group according to their b-value. The 2 average $b$-values representing the 2 main groups are significantly different (Students' $t, p<0.001$ ). Examples of normalized frequency distributions ( $d N / N$ ) are given for each group in Fig. 3.

In the first type of distribution (Group 1) over $95 \%$ of TEP occurred in the first 2 size classes ( $25 \mu \mathrm{m}$ ) and more than $60 \%$ were smaller than $10 \mu \mathrm{m}$. This group includes all spectra fitting a power-law relationship with a value of $b$ between 2.9 and 3.9 (average $b=$ $3.3 \pm 0.3$, median $b=3.31$. In this group, the fit of the regression lines to the data was extremely tight, indjcating a good fit to the power-law distribution. All size 

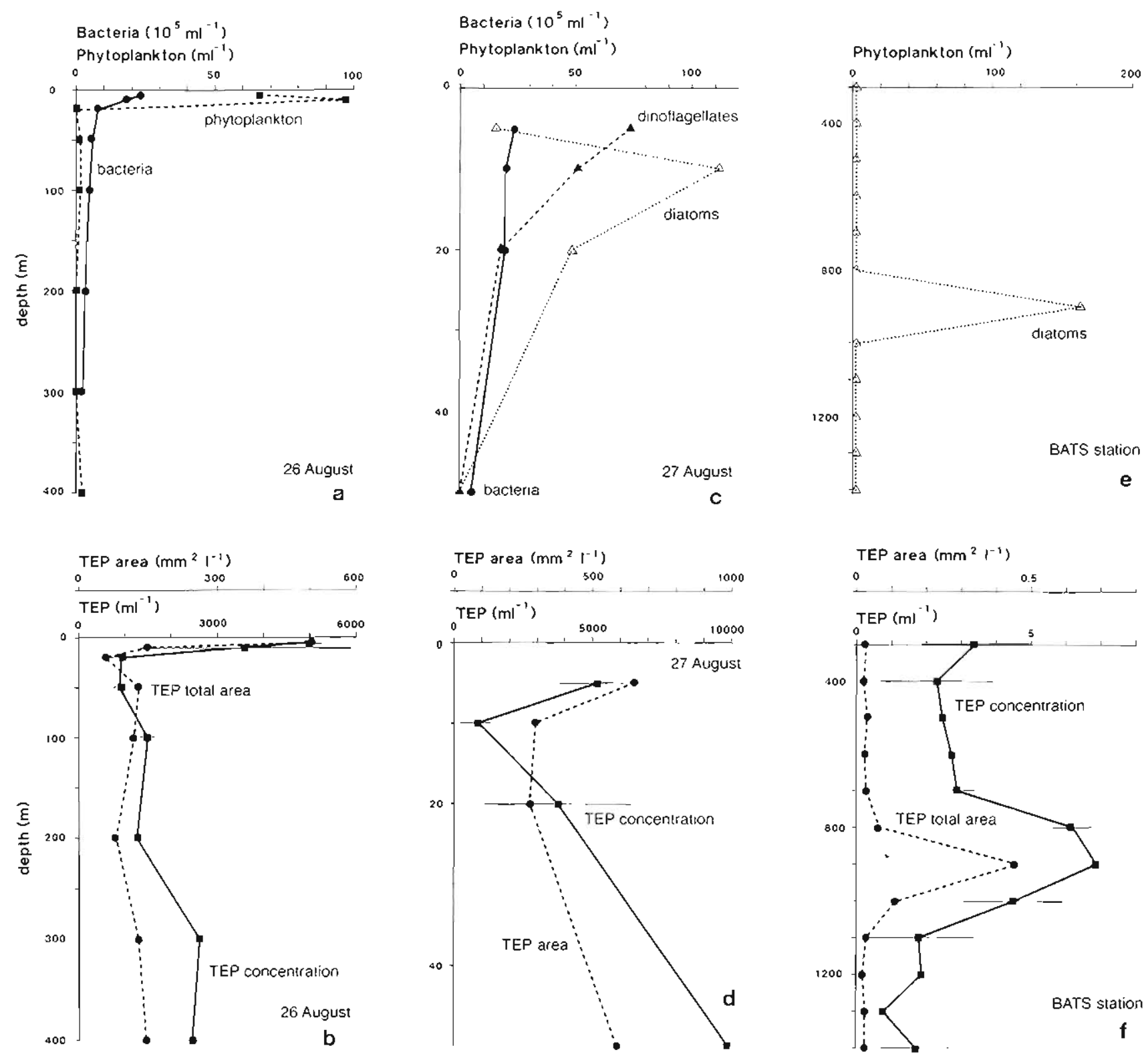

Fig. 1. Vertıcal profiles of mıcro- and bacterioplankton and of TEP abundance and total area at (a, b) a deep station (26 August 1992) and (c, d) a shallower station (27 August 1992) in Monterey Bay, and (e, 1) BATS March 1993. SD of TEP abundance often too small to show

spectra belonging to this group have in common that they were observed at stations where diatom concentrations were very low and never dominating. Dinoflagellates, ciliates or Phaeocystis were moderately abundant at some of these stations, whereas microplankton concentrations were extremely low at others. Samples belonging to this group (16) came from coastal Santa Barbara, from Monterey Bay (Fig. 2a, b) and from the open ocean (Fig. 2c). All frequency distributions from samples collected during summer in Monterey Bay (Fig. 2a, b) except the $10 \mathrm{~m}$ depth on 27 August 1992 belong in this group. The size distribu- tions observed at the BATS station between 300 and $800 \mathrm{~m}$ clearly belong to Group 1 as well ( $b=3.0$ to 3.6), but at greater depths the values of $b$ were too low to qualify.

Group 2 includes all samples (13) with a value of $b$ between 0.7 and 2.2 (average $1.6 \pm 0.45$, median 1.7). Although significant, these regressions tended to be less tight and standard deviations were higher, indicating deviations from a simple power-law distribution. Size distributions of this type were generally observed at stations where diatoms were dominating phytoplankton. Distributions collected during the early floc- 

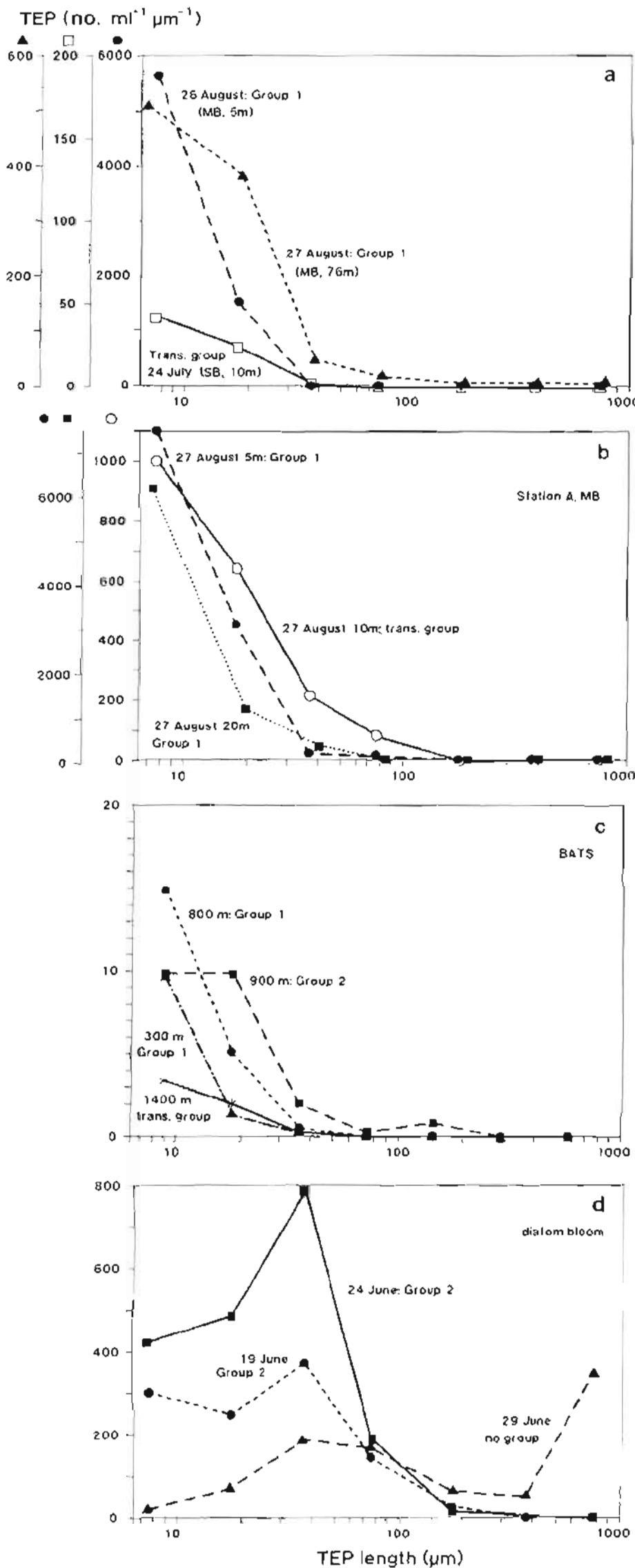

cing stage of a diatom bloom off Santa Bdrbara (19 and 24 June 1992; Fig. 2d) both belong to Group $2(b=1.6$ and 2.1 respectively). Spectra of TEP at BATS at $900 \mathrm{~m}$ (Fig. 2C), where abundance of Chaeloceros spp. was high, belong to this group as well ( $b=1.5$ ). In samples collected at 2 depths off Santa Barbara in July (after sedimentation of a bloom) and at $1000 \mathrm{~m}$ at BATS, TEP exhibited a size distribution of lype 2 ( $b=$ $1.4,1.5,2.2$ ), although no phyloplankton was present.

Size distributions of TEP observed in the presence of diatoms did not all belong into Group 2. Some spectra exhibited $b$-values too low to qualify for Group 1 and too high lor Group 2 (transition group). Samples collected at an early stage of the diatom bloom $(b=2.7)$ and the sample from Monterey Bay from $10 \mathrm{~m}$ on 27 August 1992 [ $b=2.6$; Fig. 2b] where diatoms were dominating a mixed summer assemblage, have spectra of TEP belongung to the transition group. in all samples exhibiting spectra belonging to the transition group diatoms dominated phytoplankton, except at depths below 1000 m at BATS, where no phytoplanklon was present (Fig. 2c).

Size distributions of TEP observed during the late floccing stage of a diatom bloom off Santa Barbara (10 m) had a different shape (Fig. 2d) The size distributions of TEP from 26 and 29 June 1992, when the bloom was fully flocced, did not follow a power-law distribution and did not fil in either group.

\section{Bacteria attached $10 \mathrm{TEP}$}

The number of bacteria attached to individual TEP was not correlated to the size of the respeclive TEP (Fig. 4a). Most TEP were smaller than

Fig. 2. Size distribulions of TEP in the field. (a) Total abundance (sum of $N$ ) ranges from 2.5 to 5000 TEP $\mathrm{m}^{-1}$. Three examples from Santa Borbara (SB) 24 July at $10 \mathrm{~m}(b=2.8)$ and Monterey Bay (MB) near-shore 26 Angust at $5 \mathrm{~m}(b=3.0)$ and offshore 27 August at $76 \mathrm{~m}(b=3.0)$. (b), $c)$ The shape of the size distribution of TEP may vary with depth. Examples from (b) Monterey Bay (MB) 27 August at s, 10 and $20 \mathrm{~m}(b=3.0,2.6$ and 3.4 respectively) and (c) BATS a $300,800,900$ and $1400 \mathrm{~m}$ ( $b=3.6,3.3,2.2$ and 2.8 respeclively) (d) The shape or the size distributions of TEP may change during the flocculation of diatom blooms. Example from the Santa Barbara channel during a Chaetoceros spp. bloom at $10 \mathrm{~m}$ depth on 19. 24 and 29 June $(b=1.6$, 2.1 respectively, 29 June does not bollow a power-law distribution? 
Fig. 3. Normalized size-frequency distributions of TEP. Examples of the 4 different types of distributions observed. The distribution from 26 August belongs to Group I (non-diatoms). that from 24 June to Group 2 (floccing diatoms), that from 27 August to the transition group (nonfloccing diatons) and that from $29 \mathrm{june}$ does not lit into any category (flocced diatoms)

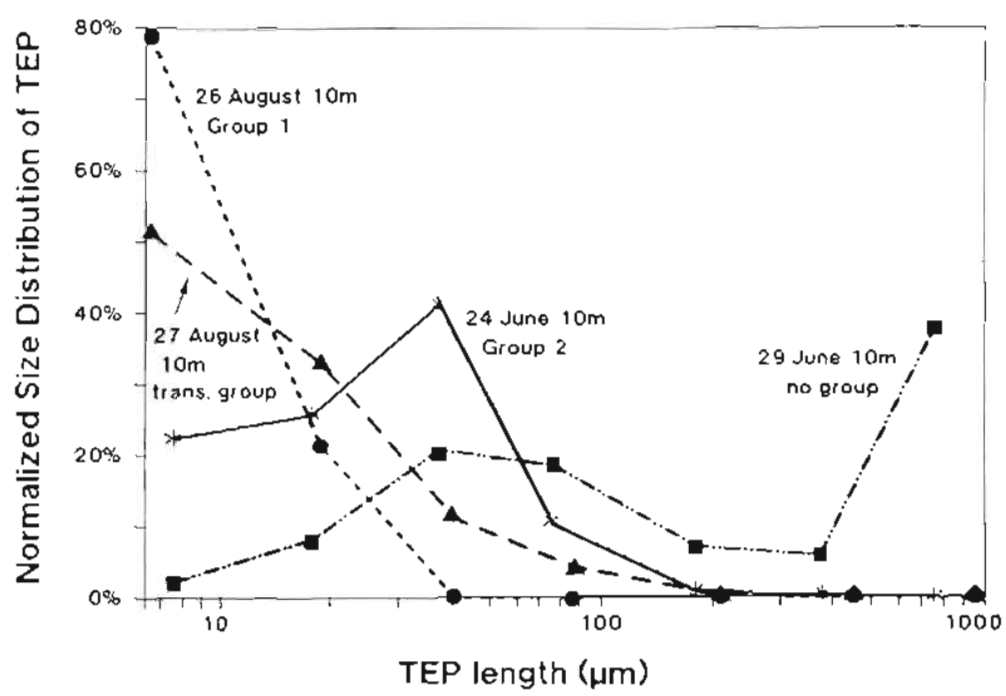

$50 \mu \mathrm{m}$ and carried less than 100 bacteria, but up to 900 bacteria were abserved per particle. Stainable thin sheets of TEP, especially very large ones (>200 $\mu \mathrm{m})$, carried comparably low abundances of bacteria.

However, the baclerial abundance per area of TEP is a significant function of TEP size (Fig. 4b). Whereas small TEP $(<10 \mu \mathrm{m})$ had 2 bactena attached per $\mu^{2}$, less than 0.1 bacteria were atlached per $\mu \mathrm{m}^{2}$ of TEP on TEP $>100 \mu \mathrm{m}$. There was no appreciable difference in baclerial density between TEP collected during the diatom bloom and TEP collected at other times.

Total abundance of bacteria in a sample was not correlated to total quantity of TEP (Fig. 5a). The raction of bacteria attached to TEP (Fig. SU) generally ranged between 2 and $25 \%$ ( 1 exception on 27 August 1992 at $50 \mathrm{~m}: 89 \%$. No difference in altached bacteria was observed beiween TEP collected during the diatom bloom study and TEP collected at other times.

\section{TEP in cultures}

\section{Abundance}

TEP found in batch cultures of diatom species generally had a similar overall appearance to TEP found in nature. However, abundance and size of TEP generated by different species differed appreciably (Table 2). TEP observed in cultures of Chaetoceros gracilis were very small (3 to $5 \mu \mathrm{m}$, average $4 \mu \mathrm{m}$ ) and comma-shaped

Fig. 4 (a) Tatal number abundance of bacleria per individual TEP versus size of the respective TEP. (b) Bacteria density per area TEP versus the size of the respective TEP 

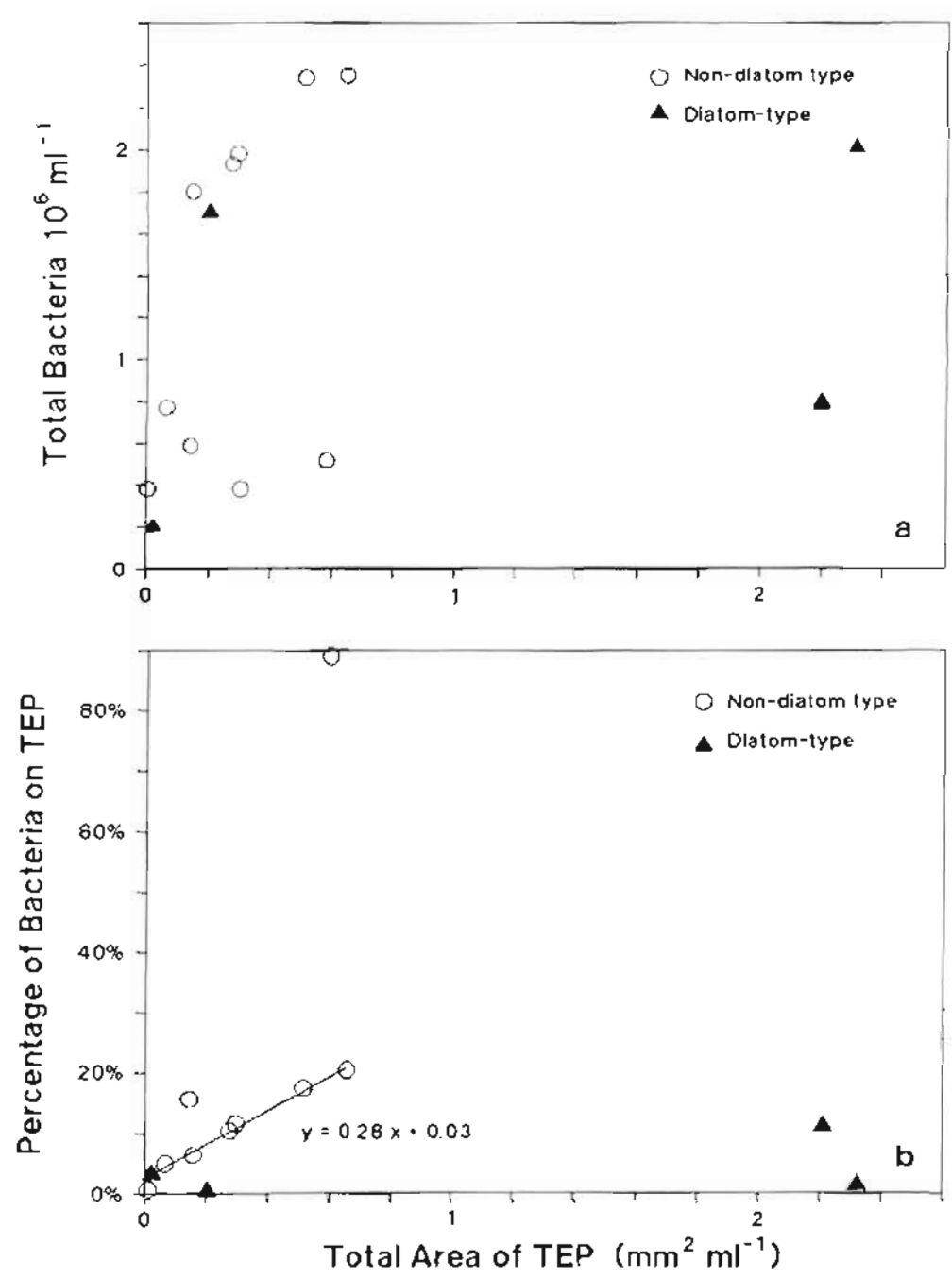

Fig. 5 (a) Total bacteria number per sample versus tolal quantity of TEP. (b) Fraction of bacteria attached to TEP versus the total quantity of TEP per sample. Regression calculated omitting the 2 values of the flocced bloom and the $89 \%$ value duced 3500 TEP $\mathrm{ml}^{-1}$ within the tjrst $2 \mathrm{~d}$ (early exponential phase). but no significant change was observed thereafter (Fig. 6b). Most TEP were large $(10$ to $25 \mu \mathrm{m}$ ) and lotal quantity of TEP was high compared to C. gracilis. TEP generated by Nitzschia angularis belonged mosily to the smallest size class, but larger particles were abundant (Fig. 6c). TEP from $N$. angularis was circular or square-shaped and an order of magnitude less abundant than C. gracilis. The decrease of total TEP abundance on Day 5 (late exponential phasel was presumably an artefact, as $N$. angularis forms mats which contain TEP on flask walls. These could not be sampled quantitalively. As maximal cell density and cell sizes of these 3 species differ considerably (Fig. 6), the specific quantity of TEP generated (tolal area of TEP/total volume of cells) was calculated (Table 2). According to those calculations $C$. gracilis produced the most TEP per cell volume. Compared to the large difforcnces in number abundance of TEP betworn species, the specific quantity of TEP produced was, however, remarkably similar.

No TEP was found in cultures of colonial Phaeocystis even in stationary phase as long as colonies did not disintegrate. In senescence when colonies began to dusintegrate, the fragments of the disrupted colonies stained blue. Although formed differently from diatom TEP, these particles may be classified as TEP and could play an important part for the formation of marine snow after Phaeocystis blooms (Passow \& Wassmann 1994).

\section{Size-frequency distributions}

Most of the size frequency spectra of TEP during the growth cycle of Chaetoceros grachis betong

Tabje 2. Characteristics of TEP generated in cultures of diatoms

\begin{tabular}{|c|c|c|c|}
\hline Species & $\begin{array}{c}\text { Maximal abundance } \\
\left.\text { (no } \mathrm{ml}^{-1}\right)\end{array}$ & $\begin{array}{c}\text { Maxinial lotal area } \\
\left(\mathrm{mm}^{2} \mathrm{ml}^{-1}\right)\end{array}$ & $\begin{array}{l}\text { Specific production } \\
\left(\mathrm{mm}^{2} \text { TEP mm }\right. \\
-4 \\
\text { cell }\end{array}$ \\
\hline Cbaeloceros gracilis & 8000 & 0.6 & 104.5 \\
\hline Thalassiosira weissflogii & 3500 & 1.5 & 847 \\
\hline Nitzschiu angularis & $800^{\prime 2}$ & 0.05 & 347 \\
\hline
\end{tabular}


to Group 1. Initially, at the beginning of the exponential phase (Day 3 ) the value of b was exceptionally high ( $b=4.2)$, decreased during exponential growth (to 3.6 on Day 9), but increased slightly at the beginting of the stationary phase, before it clecreased drastically (Day 13, $b=2.4$ ) al late stationary phase (Fig. 7a). TEP produced in the culture of Nizschia angularis exhibited at cally exponertial phase a distribution belonging to Ginup $2[b=2.1)$. Size spintra of TEP generated by Thalassiosira weisslogu did not follow a power-law distribution.

\section{Flocculation experiment}

The change in size specira of TEP observed during a flocculation experiment with Chaetoceros gracilis illustrates bow aggregation processes alter the size distribution of TEP (Fig. 7b). Injtially the size specIra of TEP fitted a power-law distribution with a $b$-value of Group $1(b=3.2)$, but during the aggregation $b$-values decreased and the fit to a power-law function began to deteriorate (after 4 and 8 min $b=2.3$ and 0.9 respectively). After 20 min rotation the size distribution of TEP did not fit a power-law lunction any more and the highest abundance of TEP was found in the third slze class, at $100 \mu \mathrm{m}$.

\section{DISCUSSION}

\section{Distribution of TEP}

The general distribution pattern of TEP in the ocean was similar to that of phytoplankton: TEP was found to be more abundant in coastal areas than in the open ocean and more abundant in the trophogenic zone than below. The ranges of concentrations and sizes of TEP in the ocean were similar to those of phyloplankton. Nevertheless, no simple overal relationship between ambient phytoplankton and TEP concentration was observed. Phytoplankton composition, however, appeared to be an important factor. Concentrations of TEP teuded to be low when diatoms dominated phyloplankton. but average size and total area of TEP were large compared to stations where diatoms were scarce.
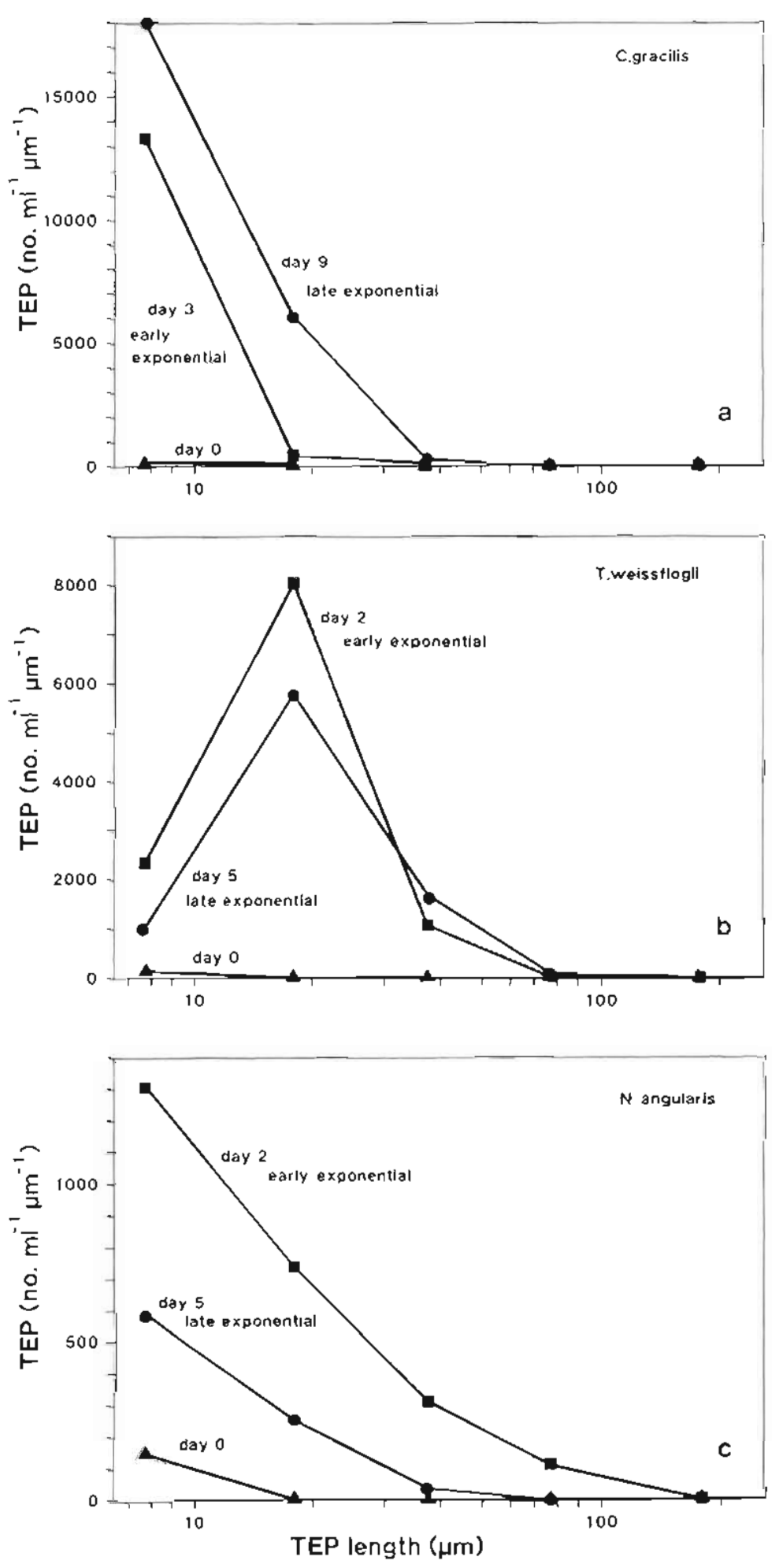

Fig. 6 Size-frequency distribution [d(N/log I) vs log $/$ of TEP before inoculation of the merdia (Day 0) and during early and late exponential growth phase of the 3 diatom cultures. (a) Chaetoceros gracilis. Early: Day $3\left(2 \times 10^{5}\right.$ cells $\left.\mathrm{ml}^{-1}\right)$ : late: Day $9\left(10^{6}\right.$ cells $\left.\mathrm{m}^{-1}\right)$. (b) Thalassiosira weissflogii. Early: Day $2\left(2 \times 10^{4}\right.$ cells $\left.\mathrm{m}^{-1}\right)$; late: Day $5\left(7.7 \times 10^{4}\right.$ cells $\mathrm{ml}^{-1}$ ). (c) Nitzschia angulars. Early: Day $2\left(7 \times 10^{3}\right.$ cells $\left.\mathrm{ml}^{-1}\right)$; late: Day 5 $\left\{2 \times 10^{4}\right.$ cells $\left.\mathrm{m}^{-1}\right\}$ 

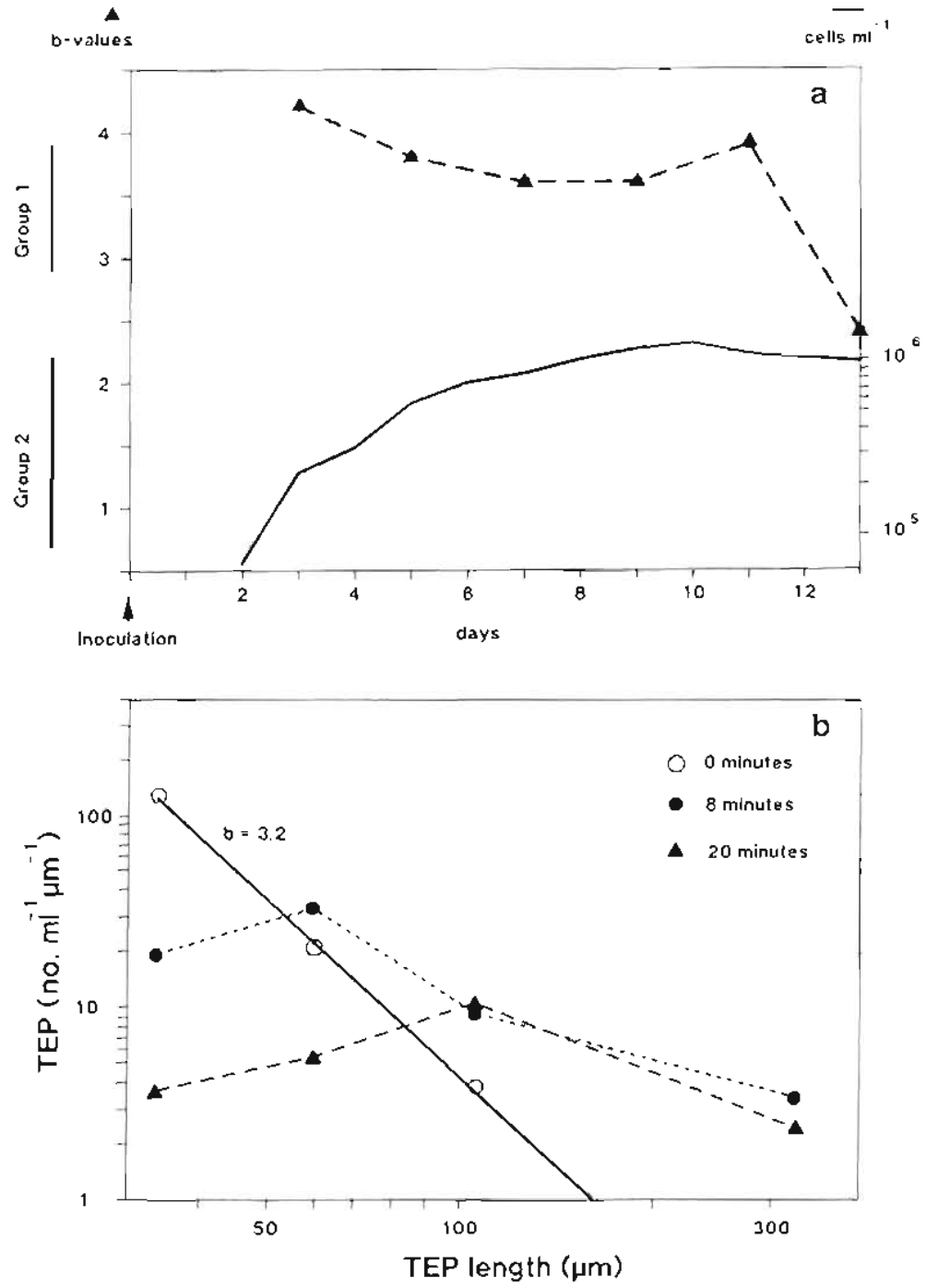

Fig. 7 . (a) Change of b-value during growth of Chaetoceros gracilis. Cell concentration was determined daily. (b) Change in the shape of size spectra of TEP during flocculation of $C$. gracilis

\section{Theory of size spectra and assumptions}

Particie size distributions reflect interactions between particles. Marine particulate matter can generally be fitted by a power-law distribution. The shape of size distributions of marine suspended particles between 1 to $100 \mathrm{\mu m}$, or even up to $1000 \mu \mathrm{m}$, appear to be essentially constant as reflected in a constant value of the logarithmic slope of the size distributions $(b=4)$ [Sheldon et a]. 1972, La] \& Leman 1975, Lerman et a]. 1977. Hunt 1980, 1982, McCave 1984). Reasons for such a constant size distribution of marine suspended matter are, however, controversial and it has been suggested that distributions of individual particle types may not follow a power-law distributions, but that the overall distributions are made up of log-normal distrib- utions of component particles (Lambert et al. 1981, McCave 1984).

Under the assumption of constant production of particles into the smallest size class (to keep the flux of material through the spectrum constant] coagulation due to shear and loss of large aggregates due to sedimentation will create steady-state size spectra which fit a power-law distribution with $b=4$ (Lerman 1979, Hunt 1980, 1982 McCave 1984). The effect of aggregation on size distributions depends, however, on the mechanisms (Brownian motion, shear, differential seluing) governing coagulation (Hunt 1980, 1982).

As dissolution is faster for smaller than for larger particles the slope of the resulting size distribution would decrease (smaller b) if only dissolution occurred (Lerman 1979). Frigmentation or disaggregation on the other hand lead to a residual distribution with a steeper slope ( $b$ larger, more smaller particles) (Lerman 1979). Filtration mechanisms, like grazing of zooplankton, may not change the shape of the curve (if they are effective over the whole size range), but reduce the lotal number of particles (change in A).

It is not known whuch processes significantly alter abundance and distribution of TEP. The shapes of size distrbutions may indicate which processes are of primary importance for TEP. In the following discussion the size spectra of TEP observed in different environments will be analyzed. making the following assumptions:

(1) A power-law distribution with $b=4$ represents a theoretical steady-slate situdtion, where production of small TEP is balanced by loss of coagulated TEP. We will use this value as a reference point in our discussion.

(2) For strady-state conditions to occur particles must be generated continuously into the low end of the size spectra. TEP is formed from dissolved excretion products of phyloplankton via coagulation of microfibrils (Alldredge el al. 1993, Passow et al. 1994). Newly formed TEP will accordingly be introduced into the low end of the size spectum.

(3) As TEP are relatively large but do not sink appre. ciably (unpubl. data), it is assumed that coagulation of TEP is dominated by shear.

(4) Furthermore, it will be assumed that TEP is primarily generated by phytoplankton and that production of TEP ceases in the absence of phytoplankton. Presumably TEP is also generated by excretion prod- 
ucts of bacteria, but no relationship between bacteria and TEP abundance was observed.

(5) It is assumed that TEP generated by difterent species have different properties. TEP differed considerably in size, shape and abundance between species. The role of TEP during aggregation also differs for different species (Crocker \& Passow in press). The stickiness of TEP produced by Chaetoceros gracilis is high (Passow et al. 1994), whereas TEP of Nitztschia anguJaris and Thalassiosira weissllogii do not appear to be sticky (Logan et al. 1994). Kiorboe \& Hansen (1993) found TEP from Rhodomonas baltica and Skeletonema costatum not to be sticky, whereas Coscinodiscus sp. generated TEP that coagulated easily.

\section{Size spectra of TEP}

\section{In culture}

Size spectra observed in cultures may help interpret field data, as batch cultures are relatively simple systems (no loss from sedimentation, consumption). Total quantity and abundance of TEP increased during the growth cycle of Chaetoceros gracilis and the system was far from steady state. Changes in the size spectra of TEP during growth of $C$. gracilis may be explained by the interaction between production and aggregation of TEP. Initially the $b$-value was very high (4.2) and close to the steady-state equilibrium postulated if introduction of new (small) particles is balanced by coagulation and loss of large aggregates (Hunt 1980 . 1982). During the exponential growth phase the $b$ value of the spectra of TEP decreased continuously (to 3.6 on Day 9), suggesting that coagulation was slightly faster than production of TEP. At the onset of the stationary phase the formation rate of TEP increased appreciably, apparently now dominating, as the percentage of small particles increased. Altbough production rate of TEP stayed high during the stationary phase, the $b$-value dropped drastically, indicating that aggregation dominated interactions of TEP at this time. In the flocculator high shear rates made coagulation of TEP important on time scales too short for production of TEP to be of significance. The initial decrease in $b$-values as flocculation began and the subsequent deviation from a power-law distribution during the floccing phase describe this aggregation dominated system.

\section{In the presence of diatoms}

In the field, size spectra of TEP observed in the presence of diatoms belonged either to Group 2, the transi- tion group or did not follow a power-law distribution. The sequence of spectra of TEP collected during the floccing bloom evolved similarly to those observed for Chaetoceros gracilis in the flocculator, suggesting that coagulation of TEP dominated processes altering size distributions of TEP in these samples. The inclusion of a specific spectra in one of the groups also appeared to correspond to the degree of flocculation of the diatoms. Size distributions of TEP belonging to the transition group were observed when diatoms were not floccing. The size distributions of TEP did not follow power-law distributions when a bloom was fully flocced. Size spectra belonging to Group 2 indicated that macroscopically visible flocs would form within days. This implies that microscopically visible coagulation of TEP preceeds the macroscopical flocculation of a bloom, suggesting that size spectra of TEP may have predic. tive value.

Diatom assemblages were mostly Chaetoceros spp. dominated bloom-diatoms. Our experiments as well as data from others (Kiørboe \& Hansen 1993, Kiørboe et al. 1994) indicate that TEP may be less important during flocculation of other diatom species.

A size spectrum near equilibrium conditions (belonging to Group 1) was never observed in the presence of diatoms in nature. Processes like dissolution or selective consumption of smaller TEP may have caused the observed deviations from a steady-state situation However, as effects of dissolution were not visible in cultures, we do not assume this to be a process of major importance. Size distributions with $b$-values below 4 would also be expected. if TEP were fractal. In fact, under the assumption of steady state the fractal dimension of aggregated particles may be calculated from $b$-values (Jiang \& Logan 1991, Logan \& Kilps 1994). As aggregates formed in marine systems generally have fractal properties (Logan \& Wilkinson 1990, Kilps et al. 1994). we suggest that the low $b$-values during growing (non-floccing) diatom blooms may reflect in part the fractal nature of TEP aggregates.

\section{In the presence of non-diatom phytoplankton}

Size spectra of TEP in the presence of non-diatom phytoplankton belonged to Group 1. These distributions may represent conditions near steady state, where coagulation of TEP is balanced by production of TEP. Large aggregates were never observed at these stations, making an appreciable loss of TEP due to sinking unlikely. If loss was low, both production and coagulation of TEP must have been low. Size spectra of TEP observed in the presence of non-diatom phytoplankton never belonged to Group 2 or the transition. group, which also indicates that coagulation never 
dominated size distributions of TEP in these samples. Low coagulation rates suggest that TEP from nondiatom phytoplankton may be less sticky than diacomTEP. The higher $b$-values may furthermore indicate that non-diatom TEP is less fractal than TEP generated by diatoms.

In the absence of phytoplankton

The size distributions of TEP in the absence of phytoplankton were not predictable and presumably depend on the phytoplankton assemblage which generated TEP prior to sampling. In July, after the sedimentation of the diatom bloom, the size distribution of TEP belonged to Group 2 and probably reflected the flocced bloom, although phytoplankton (and most TEP) had sedimented. A FEP size spectra belonging to Group 2 was also observed at $1000 \mathrm{~m}$ at BATS, below the layer abundant in Chaetoceros spp. Size distributions of TEP from below the euphotic zone (oceanic and coastal) generally belonged to Group 1. As TEP are presumably not generated below the euphotic zone, and as the sinking velocity of individual TEP must be very small, it may be concluded that processes changing distributions of non-diatom TEP are slow.

\section{Conclusions from analysis of size spectra}

Our field data suggesis that TEP generated by diatoms differ from non-diatom TEP. Diatom TEP appear to be more fractal and exhibit a higher stickiness. TEP produced by different dialom species also differ. The size spectra of TEP generated by diatoms furthermore differ depending on the degree of flocculation of the diatoms. Possibly, the spectra of TEP generated by diatoms may be used to make predictions about the degree of flocculation of cells, as the coagulation of TEP appears to precede the macroscopically visible flocculation of the bloom. Of all processes potentially altering size distributions of TEP, only coagulation of IEP generated by diatoms was conspicuous. All other processes seemed comparably slow and size distributions of non-diatom TEP appeared to remain unchanged over long periods, thus occurring even at great depths.

\section{Bacteria associated with TEP}

The abundance of bacteria attached to TEP was not directly related to size of TEP. Bacteria density on TEP. however, decreased with increasing size of TEP. A similas decrease in specific bacterial density with aggre- gate size (bacteria per aggregate weight vs aggregate size) occurs on marine snow (Alldredge \& Golschalk 1990). The decrease of bacterial density with TEP size may be an artefact of measuring TEP collapsed on fillers (in 2 dimensions). TEP are presumably 3 -dimen. sional and often fractal when suspended. Bacteria themselves may also influence the size of TEP, either by degradation or by generation of alcian blue stainable mucous. Bacteria attaching to surfaces have been found to excrete extracellular polysaccharides abundantly (Decho 1990. Cowen 1992. Vandevivere \& Kirchman 1993). The high variability of bacterial attachment within one size class may be caused by differences in degree of colonization, age or composition of TEP.

The relationship between total number of bacteria and total quantity of TEP does not indicate that bacteria abundance is increased by the presence of TEP. The large quantity of TEP during the floccing diatom bloom was not paralleled by a respective increase in bacteria for example. From this it may be concluded that TEP is not always a preferred energy source promoting growth of bacteria and no simple relationship exists belween TEP and bacteria abundance. The percentage of bactirid associated with TEP, however, appear to depend within certain restrictions on the total area of TEP. This could indicate that bacteria colonize TEP according to the surface area available. rather than extensively grow on TEP.

With one exception, less than $25 \%$ of all bacteria were associated with TEP. These values are lower than those reported by us earlier (Alldredge et al. 1993, passow et al. 1994). This difference is partially due to use of a different, possibly more accurate, way of calculating these percentages. Values given in the present paper should be viewed as lower estimates, whereas earlier estimates represented upper limits.

In marine pelagic environments altached bacterna arc generally reported to account for less than $5 \%$, and rarely more than $10 \%$, of the total bacteria assemblage (Hodson el al. 1981, Linley \& Field 1982). TEP contributes appreciably to marine snow (macro-aggregates), but as marine snow aggregates are generally rare, less than $5 \%$ of all bacteria are altached to marine snow (Alldredge el al. 1986, Alldredge \& Gotschalk 1990). Higher percentages (10 to 20\%) of allached bacleria were only found in river plumes or estuaries where allocbtonous detrital material is abundant and turbidity high (Ducklow \& Kirchman 1983, Painchaud \& Therriault 1989).

We believe that previous studies which have not considered TEP-attached bacteria may have underestimated the percentage of attached forms. Bacteria attached to TEP may have to be added to numbers of allached bacteria derived by most methods. Many 
melhods rely on size separation with filters (Azam \& Hodson 1977). Preliminary tests showed that TEP is extremely flexible and that TEP several tens of fim in size can be passed through a $1 \mathrm{~km}$ filter. Under the microscope, bacteria attached to TEP would be jdentified as iree bacteria without our double-staning lech. nique. Without staning only TEP which are very densely colonized, and lying in bacteria-poor surroundings, will be recognized as particles. In a detailed microscopical investigation Linley \& Fjeld (1982) describe the different kind of bacterial associations they found on the west coast off South Africa. About $85 \%$ of all micro-aggregations they observed are described as 'gelatinous aggregates' which, according to the description given, may be identical with large and heavily colonized TEP. In their study, about $5 \%$ of all bacteria were attached and $4 \%$ were attached to the 'gelatinous aggrogates'. Because of the transparency of TEP, a large fraction of bacteria associated with TEP, especially on large webs, may have been overlooked even in this careful investigation.

\section{Impact of TEP on ecology}

The variability in abundance, size and type of TEP in marine systems will result in a high variability in the relalive significance of TEP for aggregation, as a food source for zooplankton, in the carbon cycle, for the microbial community and for chemical adsorption processes.

All diatoms we investigated generated TEP, and Skeletonema costatum, Chaetoceros affinis and Coscinodiscus $\mathrm{sp}$. also produce mucous particles, presumably TEP (Kiorboe \& Hansen 1993). Heterocapsa pygmia (dinoflagellate) forms some TEP (unpub). data) and TEP or TEP-like mucous particles are also formed by Rhodomonas baltica (Kiorboe \& Hansen 1993). Colonial Phaeocystis, however, do not generate TEP except when colonies are disintegrating (Passow \& Wassmann 1994). It thus appears that most phytoplankton specjes generate TEP, and TEP were observed at all stations in natural waters, even in the absence of abundant phytoplankton.

The role TEP play in the formation of marine snow, however, varjes. The importance of TEP for aggregalion of some diatom species has been shown (Passow et al. 1994). Other diatom species, however, like Skeletonema costatum (Kiørboe et al. 1994) or Nitzschia angularis (Crocker \& Passow in press) form flocs with little TEP. The data presented here indicate that TEP generated by non-diatom species may not contribute significantly to the formation of marine snow.

TEP, especially when covered by bacteria, may be valuable food for protozoo- and zooplankton. How- ever, very large, sticky webs of TEP such as observed during floccing blooms are more likely to in hibit feeding by clogging feeding structures. Small TEP, as observed more commonly in the absence of diatoms, on the other hand, may be too small for many filter feeders

The total area of TEP was relalively small at stations where diatoms were rare, al though abundances of TEP were very high. This would suggest that in terms of the cycling of carbon TEP may be appreciably more important in connection with djatom blooms than at other times.

By serving as a substrate and presumably an energy source for bacteria, TEP may alter distribution patterns of bacteria and their availability as a food source. The degree to which TEP may be utilized by the microbial community will largely depend upon the chemical composition of TEP. As excretion products of phytoplankton vary with species (Decho 1990), it is assumed that the composition of TEP may also vary and that the high variability of bacterial colonization of TEP may reflect this.

Acknowledgements. The project was lunded by ONR (N00014-89-J3206). We thank Mark Brzezinsko and Anne Close for providing the samples from BATS and Chris Gotschalk for help with figures. We furthermore thank Bruce Logan tor valuable comments on an earlier version of this paper.

\section{LITERATURE CITED}

Alldredge, A. L., Cole, J. J, Caron, D. A. (1986). Production of heterotrophic bacteria inhabiting macroscopic organic aggregates (marine snow) from surface waters. Limnol. Oceanogr. 31: 68-78

Alldredge, A. L., Gotschalk, C. C. (1990). The relative contribution of marine snow of different otigins 10 biological processes in coastal waters. Cont. Shelf Res, 10: $41-58$

Alldredge, A. L., Passow, U., Logan, B. (1993). The existence, abutrdance, and significance of lasge transporent exopoly. mer particles in the oceon. Deep Sea Res. I 40: 11.31-1140

Azam, F.. Hodson, R. E. (1977). Size distribution and activity of marine microhelerotrophs. Limnol. Oceanogr. 22 . $492-501$

Bader. H. (1970). The hyperbolic distribution of particles J. geophys. Res. 75: 2822-2830

Cowen, J. P. (1992). Morphological study of marine bacterial capsules: implications for marine aggregates. Mar. Biol. 114: $85-95$

Crocker, K., Passow. U. (In press). Differential aggregation of Baloms. Mar. Ecol. Prog. Ser.

Decho. A. W. (1990). Microbial exopolymer secretions in ocean enviconments: their role in lood webs and marine processes. Oceanogr. mar. Biol, A. Rev. 28: 73-153

Ducklow, H. W., Kirchman, D. L. (1983). Bacterial dynamics and distribution during spring diatom bloom in Hudson River plume, USA. J. Plankton Res. 5: 333-355

Hewes, C. D. Holm-Hansen, O. (1983). A method for secovering nanoplankton from filters for identification with the 
microscope: the filter-tJansfer-freeze (FTF) technique. Limnol. Oceanogr. 28: 389-394

Hewes, C. D., Reid, F. M. I-I., Holm-Hansen, O. (1984). The quantıtative analysis of nanoplankton: a study of methods. J. Plankton Res. 6: 601-613

Hobbie, J. E., Daley, R. J., Jasper, S (1977). Use of Nuclepore filters for counting bacteria by fluorescence microsropy. Appl. environ. Microbiol. 33: 1225-1228

Hodson, R. E., Maccubbin, A. E., Pomeroy, L. R. (1981). Dissolved adenosine triphosplyare utilization by free-living and attached bacterioplankton. Mar. Biol. 64: 43-51

Horobin, R. W. (1988). Understanding histochemistry: selection, evaluation and design of biological stains. Biochemistcy and biotechnology. J. Wiley and Sons, New York

Hunt, J. R. (1980). Prediction of oceanic particle sizedistributions from coagulation and sedimentation mechanmisms. In: Kavanaugh, M. C., Leckie, S. (eds.) Particulates in water - characterization, late, elfects and removal. Adv. Chemistry 189:243-257

Hunt. J. R. (1982). Sell-similar particle-size distributions during coagulation: theory and experimental verification. J. Fluid Mech. 122: 163-185

Jiang, Q., Logan, B. E. (1991). Fraclal dimensions of aggregates determined from steady-state size disuributions. Environ. Sci. Tech. 25: 2031-2038

Kilps, J. R., Logan, B. E., Alldredge, A. L. (1994) Fractal dimensions of marine snow aggregates determined frorn image analysis of in situ photographs. Deep Sea Res. (in press]

King. L. K., Parker, B. C. (1988). A simple, rapid method for enumerating tolal viable and mecabolically active bactera in groundwater. Appl. environ. Microbiol. 54: 1630-1631

Kierboe, T., Hansen, J. L. S. (1993). Phytoplankton aggregate formation: observations of pulterns and mechanisms of cell sticking and the significance of exopolymer material. J. Plankton Res. 15: 993-1018

Kiorboe, T., Lundsgaard, C., Olesen, M., Hansen, J. (1994). Aggregation and sedimentation processes during a spring phytoplankton bloom: a field experiment to test coagulation theory. J. mar. Res. 52: 297-323

Lal, D., Lerman, A. (1975). Size spectra of biogenic particles in ocean water and sediment. J. geophys. Res. 80: 423-430

Lamberl, C. E., Jehanno, C., Silverberg. N., Brun-Cottan, J. C., Chesselet, R. (1981). Log-normal distributions of suspended particles in the open ocean. J. mar. Res. 39: 77-98

This article was submitted to the editor
Lermon, A. (1979). Geochemical processes water and sediment environments. J. Wiley and Sons. New York

Lerman, A., Carder, K. L., Beizer, P. R. (1977). Elimunation of bre suspensoids in the oceanic water column. Earth Plinel. Sci. Lett. 37:61-70

Linley, E. A. S., Field, J. G. (1982). The nature and ecological significance of bacterial aggregation in a nearshire upwelling system. Estuar coast. Shelf Sci. 14:1-11

Logan, B. E., Kilps, J. R. (1994). Fractal dimensions of aggregates formed in different fluid mechanical environments. Water Res. 39: 390-395

Logan, B. E., Kirchmann, D. L. (1991\}. Uptake of dussolved organcs by marine bacteria as a function of fluid motion. Mar. Biol. 111: 175-181

Logan, B. E., Passow, U., Alidredge, A. L. (1994). Vanable retention of diatoms on screens during size separations Limnol. Oceanogr. 39: 390-395

Logan, B. E. Wilkjnson, D. B. (1990). Fractal geometry of marine snow and other biological aggregates. Lumnol. Oceanogr. 35: 130-136

McCave. i. N. (1984). Size spectra and aggregation of suspended particles in the deep ocean. Deep Sea Res. 31. $329-352$

Parker, B. C., Diboll, A. G. (1966). Alcian stauns for histochemical localization of acjd and sulfated polysaccharides in a]gae. Phycologia $6: 36-46$

Painchaud, J., Therriault, J.-C. (1989). Relationship between bacteria, phytoplankton and particulate organic carbon in the upper St. Lowrence estuary. Mar. Ecol. Prog. Ser. 56: 301-311

Passow. U., Alldredge, A. L., Logan, B. E. (1994). The role of particulate carbohydrate exudat's in the flacculation of duatom blooms. Deep Sea Res. 41:335-357

Passow, U, Wassmann, P. (1994). On the trophic fate of Phaeocysis pouchetii (Hariot): IV. The formation of marme snow by P. poucheti. Mar. Ecol. Prog. Ser. 104: 153-161

Porter, G. K., Feig. Y. S. (1980). The use of DA.PI for identyying and counting aquatic microflora. Limnol. Oceanogr. 25: $943-948$

Sheldon, R. W., Prakash, A., Sutcliff, W. H. JT (1972). The size distribution of particles in the ocenn. Limnol. Oceanogr. 17: $327-340$

Vandevivere, P., Kirchman, D. L. (1993). Attachment stimulates exopolysaccharide synthesis by a bacterium. Appl. environ. Micrubiol. 54: 3280-3286

Manuscript first received: Jânuáry 25, 1994

Revised verston accepled: June 8. 1994 